\title{
First Triassic tetrapod (Sauropterygia, Nothosauridae) from Castilla y León: evidence of an unknown taxon for the Spanish record
}

\author{
C. de Miguel Chaves ${ }^{1}$, S. García-Gil2 ${ }^{2}$ F. Ortega ${ }^{1}$, J.L. Sanz ${ }^{3}$, A. Pérez-García ${ }^{1}$ \\ ${ }^{1}$ Grupo de Biología Evolutiva, Facultad de Ciencias, UNED, Paseo de la Senda del Rey 9, 28040, Madrid, Spain. \\ ${ }^{2}$ Departamento Geociencias Marinas y O.T., Facultad Ciencias del Mar, Universidad de Vigo, 36310, Vigo, Spain. \\ ${ }^{3}$ Unidad de Paleontología, Departamento de Biología, Facultad de Ciencias, Universidad Autónoma de Madrid, Calle Darwin 2, 28049, \\ Madrid, Spain. \\ e-mail addresses: carlos.miguelchaves@gmail.com (C.M.C.), sgil@uvigo.es (S.G-G),fortega@ccia.uned.es (F.O.),dinoproyecto@gmail.com (J.L. \\ S.), paleontologo@gmail.com (A.P-G)
}

Received: 11 November 2015 / Accepted: 1 February 2016 / Available online: 30 April 2016

\begin{abstract}
Several vertebrae of a sauropterygian specimen have been recovered in Fuencaliente de Medinaceli (Soria Province, Castilla y León, Spain). The remains come from late Middle Triassic levels (late Ladinian) of the upper Muschelkalk Facies. This finding represents the first documented evidence of a Triassic tetrapod in Castilla y León. The vertebrae belong to Nothosaurus, a sauropterygian genus found in Europe, Middle East, North of Africa and China. This genus is poorly-known in the Iberian record. The new remains constitute the first evidence of the species Nothosaurus giganteus, or a related taxon, in the Iberian Peninsula, being referred as Nothosaurus cf. giganteus. This study reveals the occurrence of at least two species of the sauropterygian Nothosaurus in the Iberian record.
\end{abstract}

Keywords: Muschelkalk, Nothosauria, Nothosaurus, Iberian Ranges, Spain

Resumen

Varias vértebras de un ejemplar de sauropterigio han sido encontradas en Fuencaliente de Medinaceli (Provincia de Soria, Castilla y León, España). Los restos provienen de niveles del Triásico Medio tardío (Ladiniense superior) de la parte superior de las Facies Muschelkalk. Estos elementos representan la primera evidencia documentada de un tetrápodo triásico en Castila y León. Las vértebras pertenecen a Nothosaurus, un género de sauropterigio encontrado en Europa, Oriente Próximo, el norte de África y China. Este género es mal conocido en el registro ibérico. Los nuevos restos constituyen la primera evidencia de la especie Nothosaurus giganteus, o de un taxón emparentado, en la Península Ibérica, siendo atribuidos a Nothosaurus cf. giganteus. Este estudio revela la presencia de, al menos, dos especies diferentes de Nothosaurus en el registro ibérico.

Palabras clave: Muschelkalk, Nothosauria, Nothosaurus, Iberian Ranges, España

\section{Introduction}

Remains of Spanish Triassic sauropterygians have been found at several localities from the eastern half of the Iberian Peninsula, and at the Balearic Islands. These elements, most of them being isolated or fragmentary remains, were recovered from Aragon (Kuhn-Schnyder, 1966; Lapparent, 1966; Sanz, 1976; Rubio et al., 2003; Miguel Chaves et al., 2015), Andalusia (Sanz, 1991; Alafont, 1992; Niemeyer, 2002; Reolid et al., 2013); Balearic Islands (Bauza Rullán, 1955); Castilla-La Mancha (Lapparent, 1966; Westphal, 1975; Sanz, 1980; 1983; 1991; Alférez et al., 1983; López-
Gómez, 1985; Alafont, 1992; 1999; Quesada et al., 2009), and Catalonia (Almela and Llopis, 1947; Sanz, 1980; 1983; Alafont and Sanz, 1996; Rieppel and Hagdorn, 1998; Quesada and Aguera González, 2005; Fortuny et al., 2011). The study of most of these fragmentary sauropterygian remains only provided a poorly-detailed systematic determination, allowing the identification of indeterminate pachypleurosaurs, nothosauroids and pistosauroids, as well as cyamodontoid and no cyamodontoid placodonts. However, some findings were determined at generic or specific level: the placodont Paraplacodus Peyer 1931a (Pinna, 1990); the nothosauroid Simosaurus Meyer 1842 (Miguel Chaves et al., 2015); and 
the nothosaurs Lariosaurus balsami Curioni 1847 (Sanz, 1976), "Ceresiosaurus" sp. Peyer 1931b (a junior synonym of the genus Lariosaurus sensu Rieppel, 1998a) (Quesada and Aguera González, 2005), Nothosaurus cymatosauroides Sanz 1983 (the validity of which was doubted by Rieppel, 2000) (Sanz, 1980; 1983), as well as several sauropterygian remains classified as Nothosaurus sp. (Kuhn-Schnyder, 1966; Alférez et al., 1983; Niemeyer, 2002; Reolid et al., 2013).

A new finding corresponding to material of a Spanish sauropterygian individual is described here. Its morphology is not compatible with other Iberian Triassic sauropterygians, so it cannot be assigned to any of the previously identified taxa in the Iberian Peninsula. The new specimen is represented by several vertebral elements, recovered from late Ladinian levels (Middle Triassic) of Fuencaliente de Medinaceli (Soria Province, Castilla y León) (Fig. 1A-B). It represents the first reference to a Triassic tetrapod in Castilla y León, the largest Autonomous Community of Spain, located in the northern half of the Iberian Peninsula. For sampling abbreviations: UPUAM, Unidad de Paleontología, Universidad Autónoma de Madrid, Madrid, Spain.

\section{Geological context}

The vertebrate remains studied here were found in Fuencaliente de Medinaceli (Medinaceli, Soria Province, Castilla y León; latitude $41^{\circ} 8^{\prime} 10^{\prime \prime} \mathrm{N}$, longitude $2^{\circ} 27^{\prime} 30^{\prime \prime} \mathrm{W}$ ), a locality situated in the northwestern region of the Iberian
Ranges, near the limit with the Central System (Fig. 1). This is an important region due to the limit between the Iberiantype Triassic and Hesperian-type Triassic is identified there (García-Gil, 1991). For this reason, the stratigraphic succession recorded in this area varies from the eastern part (Iberian Triassic) to the West (Hesperian Triassic). The Iberian-type is characterized by the presence of a single carbonate bar in the Muschelkalk Facies, and more specifically corresponding to the upper Muschelkalk Facies or M3 in the Catalanides (Virgili, 1958). This bar is not identified in the Hesperian-type Triassic, being mainly siliciclastic.

The vertical succession of the Triassic in this region is similar to the Germanic-Type Triassic, i.e. composed of a detritical red lower section or Buntsandstein, an intermediate carbonate section or Muschelkalk, and an upper terrigenousevaporitic one or Keuper. The top of the Buntsandstein Facies corresponds to an unconformity surface, of gentle erosive relief (García-Gil, 1990; 1991) (Fig. 2A). Sedimentation restarted with the Torete variegated Siltstones and Sandstones Formation (Ramos, 1979), and the Cuesta del Castillo Sandstones and Siltstones Formation (García-Gil, 1990; 1991). The latter laterally passes to the upper Muschelkalk Facies in the western area (i.e. to the Tramacastilla Dolostones Formation, and the Royuela Dolostones, Marls and Limestones Formation,); both formations overlapping the above mentioned unconformity surface (García-Gil, 1990). The source area for the siliciclastic sediment was located in a region of high relief, located to the west.

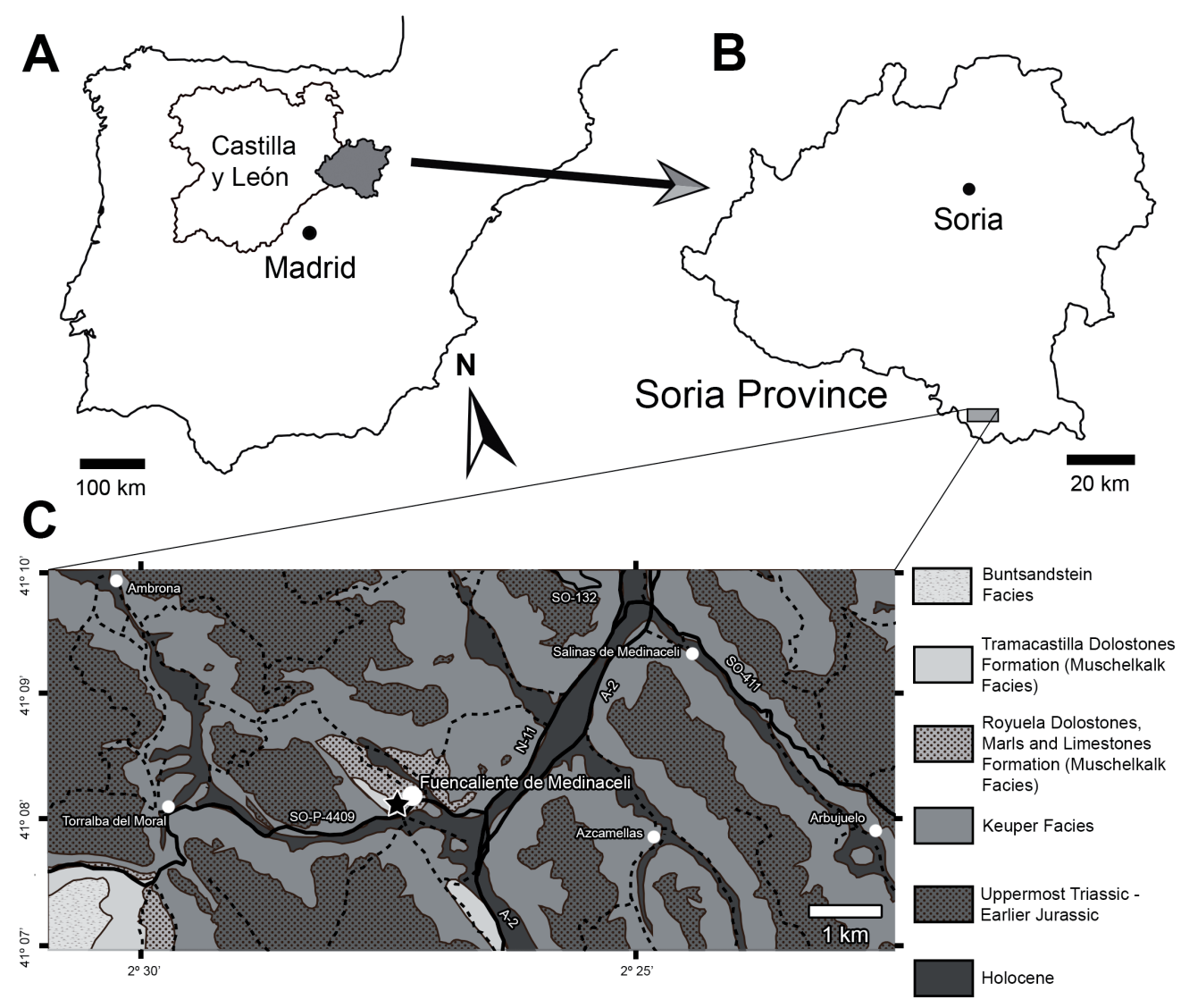

Fig. 1.- Geographical and geological situation of the upper Ladinian outcrop of Fuencaliente de Medinaceli (Soria Province, Spain) where the remains of Nothosaurus cf. giganteus studied here were found. A, situation of the Soria Province (grey) in Castilla y León and in the Iberian Peninsula. B, situation of Fuencaliente de Medinaceli in the Soria Province. C, geological map of the area of Fuencaliente de Medinaceli. Solid lines in C represent the main roads, and dashed lines indicate secondary unnamed roads. The star indicates the outcrop. Geological map modified from Adell Argiles et al. (1981). 


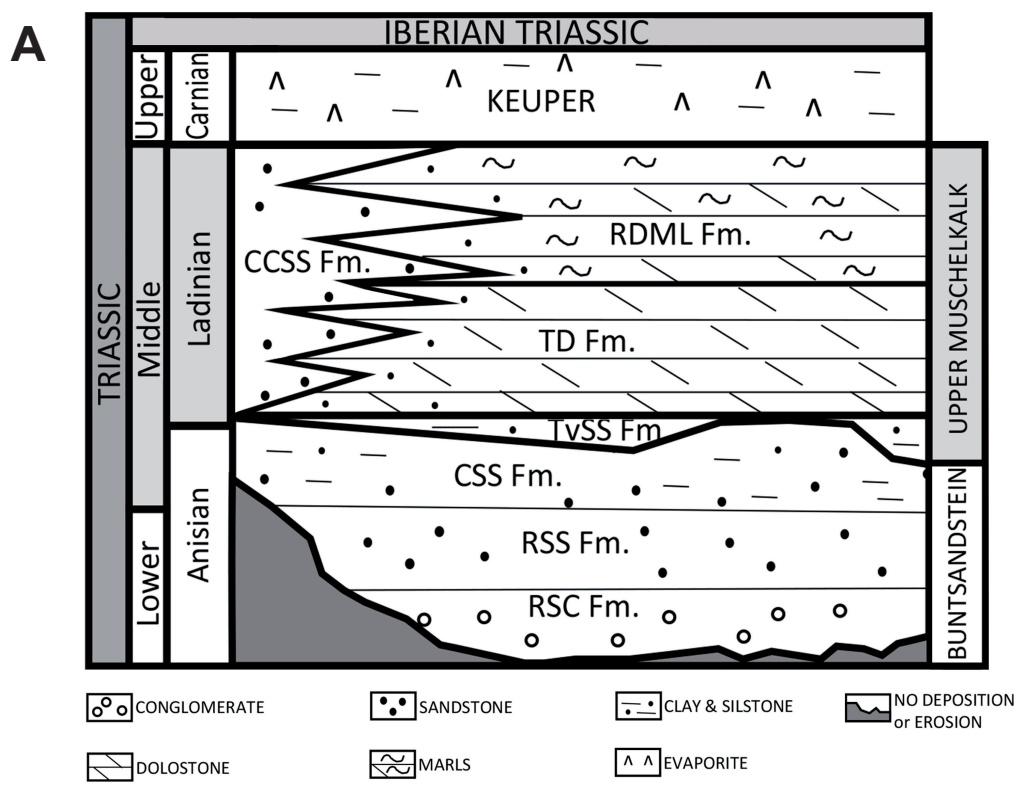

B

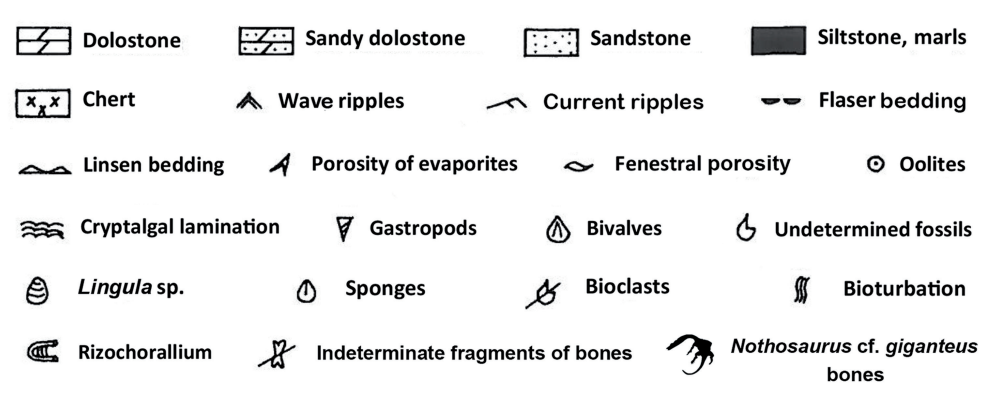

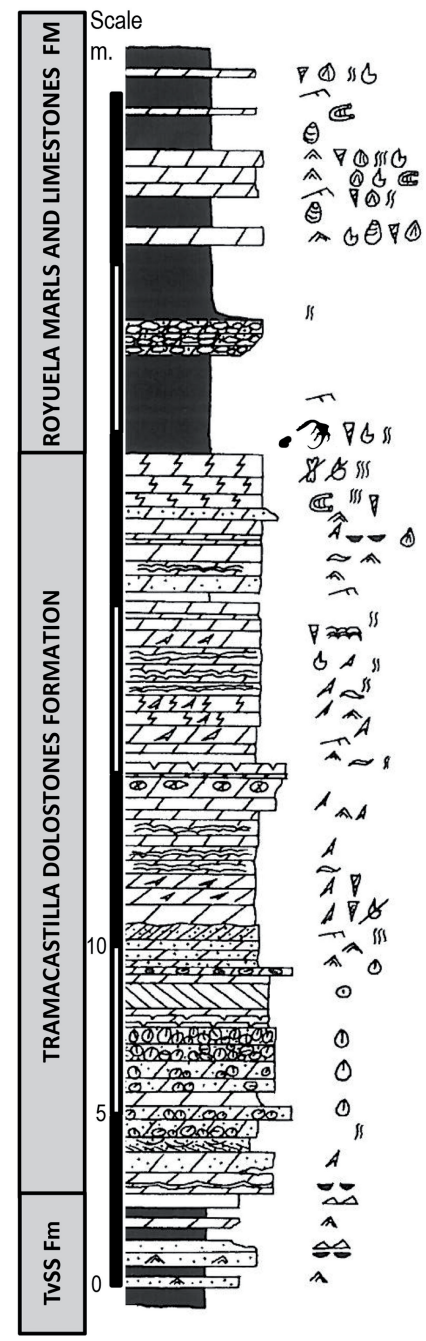

Fig. 2.- Stratigraphic context relative to the upper Ladinian outcrop of Fuencaliente de Medinaceli (Soria Province, Spain) where the remains of Nothosaurus cf. giganteus studied here were found. A, chronostratigraphic chart of the Triassic Formations in the NW Iberian Ranges. The formations are: Riba de Santiuste Conglomerates (RSC), Riba de Santiuste Sandstones (RSS), Cercadillo Sandstones and Siltstones (CSS), Torete variegated Sandstones and Silstones (TvSS), Tramacastilla Dolostones (TD), Royuela Dolostones, Marls and Limestones (RDML), and Cuesta del Castillo Sandstones and Siltstones (CCSS). Based on García-Gil (1990; 1991). B, stratigraphic section of "Fuencaliente de Medina" (sensu García-Gil, 1990) where the position of the outcrop with the Nothosaurus cf. giganteus remains is indicated. Modified from García-Gil, 1990.

The vertebrate remains described here where found in the "Fuencaliente de Medina section" (sensu García-Gil, 1990), a geological section located in Fuencaliente de Medinaceli (Fig. 2B). It is situated in the upper Muschelkalk Facies. This section comprises two Formations, the Tramacastilla Dolostones Formation and the Royuela Dolostones, Marls and Limestones Formation (Pérez-Arlucea and Sopeña, 1985), recording the northwestern-most sedimentation of the large shallow carbonate ramp from eastern Iberia (Escudero-Mozo et al., 2015). The fossil remains were recovered close to the bottom of the last mentioned Formation, within a marl horizon. These marls are grey, and appear in layers of about 2 meters thickness, with a typical polyhedral disjunction and nodular aspect. The most abundant sedimentary structures within these marls are parallel and ripple laminations, both of current and wavy type. Interbedded layers, less than 1 meter thick, of micrite dolostones with cryptalgal lamination and desiccation cracks, are also identified. Dolomitic marls and dolostones constitute shallowing upwards sequences, characteristics from sedimentation in a shallow marine carbonate environment, although they also follow by holding is mixed with carbonate terrigenous sedimentation and the fluvial influx in the North-West sector of the region (García-Gil, 1990). The marls correspond to the subtidal, while the dolostones represent the intertidal to supratidal environments.

The paleontological content described so far for these levels is composed mostly of bivalves, relatively abundant brachiopods and some gastropods (see García-Gil, 1990; 1991). Márquez-Aliaga and García-Gil (1991) grouped these fossils in three large associations: Costatoria-Lyriomyophoria, Teruel Fauna and Lingula-Pseudocorbula. They concluded that, although most of these taxa have a wide chronostratigraphic 
range (Middle Triassic), the presence of Costatoria goldfussi indicates an upper Ladinian-lower Carnian age. The study of palynological associations, and also the stratigraphic correlation, provide the same age (upper Ladinian-lower Carnian) (García-Gil, 1990; 1991), the boundary between both stages being situated close to the top of the Royuela Dolostones, Marls and Limestones Formation. Therefore, the fossil remains studied here, found at the bottom of this formation, come from the upper Ladinian (Fig 2).

\section{Systematic paleontology}

Sauropsida Huxley, 1864

Sauropterygia Owen, 1860

Eosauropterygia Rieppel, 1994

Nothosauroidea Baur, 1889

Nothosauria Baur, 1889

Nothosauridae Baur, 1889

Nothosaurus Münster, 1834

Nothosaurus cf. giganteus Münster, 1834

(Figs. 3-4)

\subsection{Material}

The vertebrate remains from Fuencaliente de Medinaceli consist of a partial axial skeleton of a single individual (UPUAM 14072), preserved in several small blocks of rock (Figs. 3-4). In addition to indeterminate fragments of bones, several vertebral remains from the cervico-dorsal region are preserved. These blocks were next to each other, forming part of a partial vertebral series that was exposed by erosion. Thus, several of the bones are broken or partially altered. The precise anatomical position of each of them is not known. This finding was the result of geological works performed in this area during the Ph.D. research of one of us (García-Gil, 1990). These remains have been partially prepared for this study. UPUAM 14072a corresponds to a block with two articulated and incomplete vertebrae (Fig. 3), and a small fragment of the neural arch of the contiguous anterior vertebra. UPUAM $14072 b$ is a block with a partial vertebra (Fig. 4A-D), and a thin layer of bone from another centrum. UPUAM $14072 \mathrm{c}$ contains a partial vertebra, and the centrum and cast of the anterior vertebral element (Fig. 4E-H). Therefore, there is evidence of, at least, seven vertebrae.

\subsection{Description}

The vertebrae from Fuencaliente de Medinaceli, especially those in UPUAM 14702a, have a robust construction. Both vertebrae in UPUAM 14702a present the neural arch and the dorsal portion of the centrum (Fig. 3). Due to the preservation, the morphology of the centra is unknown. The neurocentral sutures between the neural arch and the centrum can be recognized in both vertebrae (Fig. 3A). The neural spines are thin and oriented backwards. Although they are broken, the cast of the vertebrae in the matrix shows that the spines are low (Fig. 3A). The partially conserved second neural spine is weakly inflated apically, as can be observed in cranial and caudal views. The neural canal is filled with sediment and its morphology cannot be recognized. The transverse processes are compact, not very prominent, and tall. They are part of the neurocentral suture. The surface of articulation with the ribs constitutes an angle with the axial plane slightly less than $30^{\circ}$. The ventral region of UPUAM 14702a is medially oriented. The zygosphene can be seen in the cranial side of the anterior vertebra in UPUAM 14072a. It is well developed, with two prominent blades that conform a bipartite structure (Fig. 3B, D). The zygantrum of the anterior vertebra, and the zygosphene of the posterior vertebra, cannot be recognized, due to the articulation of both vertebrae prevents their observation. The caudal side of the second vertebra is broken and eroded. Thus, the zygantrum is lost. The anterior vertebra preserves the left prezygapophysis (Fig. 3A-C). Both prezygapophyses of the posterior one can be observed. The prezygapophyses are thin, pointed and laterally oriented both outwards as upwards. The anterior vertebra also shows most of the left postzygapophysis, but only a portion of the right one is preserved. The postzygapophyses are dome-shaped (Fig. 3A, $\mathrm{B}, \mathrm{D})$. The postzygapophysis-prezygapophysis articulation can be observed in the left side of both vertebrae (Fig. 3A). Prezygapophyses and postzygapophyses are situated in the upper part of the neural arch.

The vertebrae in UPUAM 14072b (Fig. 4A-D) and UPUAM 14072 c (Fig. 4E-H) are smaller than the two vertebrae that conform UPUAM 14072a. They are broken. Thus, they lack the neural spine, the zygantrum and all the zygapophyses. Although most part of the centra are lost, their morphology can be recognized in ventral view (Fig. 4D, H). The centra of the vertebrae in UPUAM 14072b and UPUAM 14072c are platycoelous. UPUAM 14072b preserves the left blade of the zygosphene, and also the left transverse process (Fig. $4 \mathrm{~A}-\mathrm{C}$ ). This transverse process is smaller and less prominent than those in UPUAM 14072a. As in UPUAM 14072a, the ventral region of the articular surface in the transverse process in UPUAM 14072b is medially oriented, conforming an angle of $30^{\circ}$ with the axial plane. The neurocentral suture can be seen in the left side of this vertebra, under the transverse process. A thin layer of bone is also present in the matrix, corresponding to the contiguous anterior vertebra. UPUAM $14072 \mathrm{c}$ presents the right blade of the zygosphene and the base of the left prezygapophysis (Fig. 4E-G). A partial eroded centrum of the contiguous anterior vertebra is also present in UPUAM 14072c (Fig. 4H).

Due to this material was exposed when found, several elements were lost. Therefore, the available percentage of the originally preserved skeleton is not known. The preserved remains correspond to a minimum number of seven vertebrae. However, due to their preservation, the exact position of them in the vertebral series cannot be determined. 

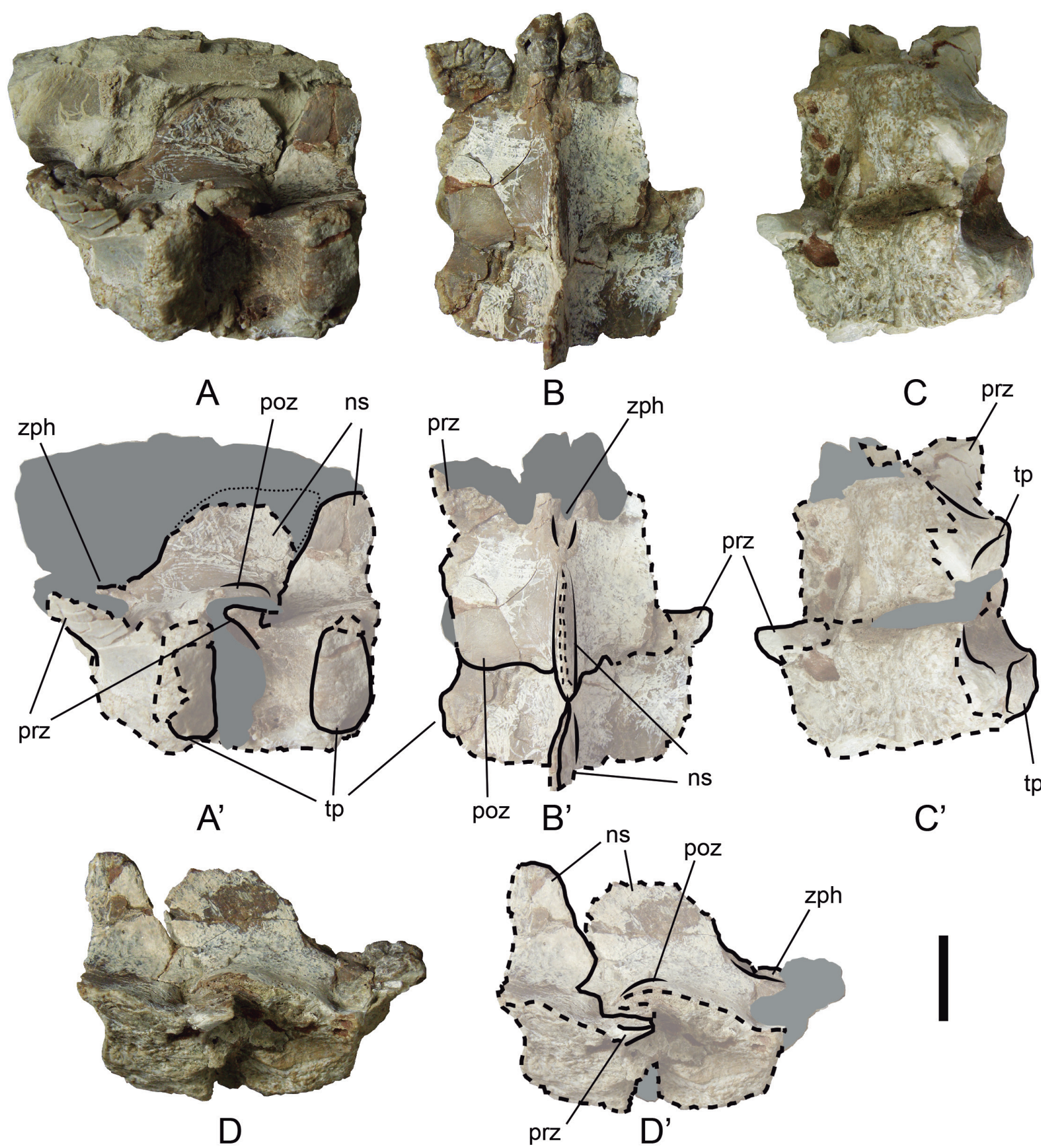

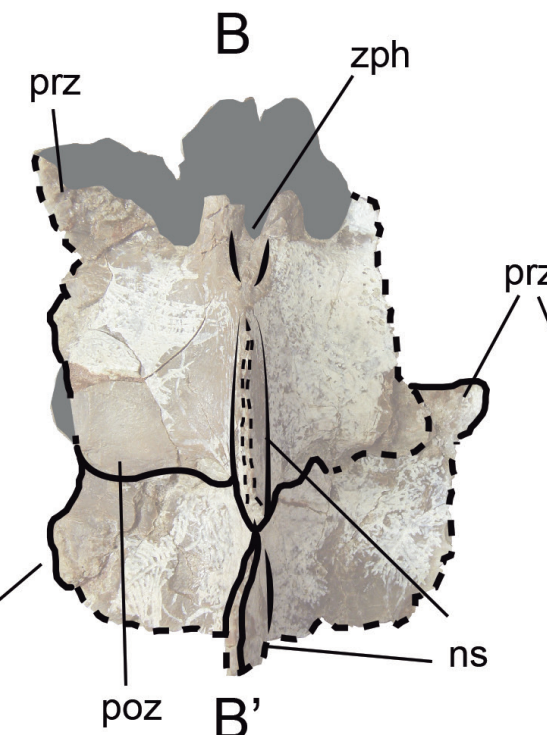

poz
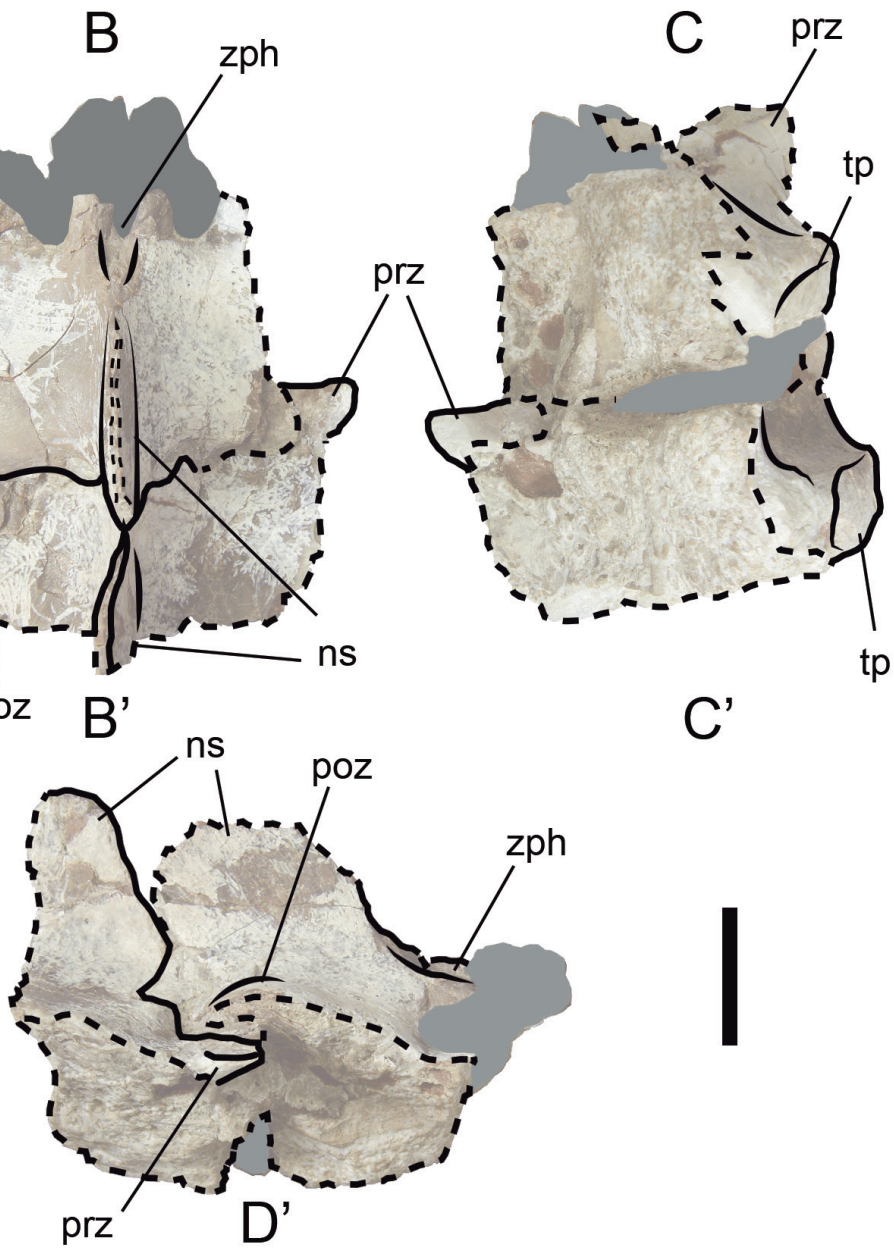

Fig. 3.- UPUAM 14702a, Nothosaurus cf. giganteus dorsal vertebrae from the upper Ladinian of Fuencaliente de Medinaceli (Soria Province, Spain), in left lateral (A), dorsal (B), ventral (C) and right lateral (D) views. A'-D', schematic interpretations of the vertebrae, in the same views. Grey areas represent sediment, dashed lines indicate broken surfaces of bone, and the line composed by points shows the silhouette of the neural spine. Anatomical abbreviations: ns, neural spine; poz, postzygapophysis; prz, prezygapophysis; tp, transverse process; zph, zygosphene. Scale bar equals 20 mm.

\section{Discussion and conclusions}

All the vertebral elements found in the upper Muschelkalk Facies of Fuencaliente de Medinaceli belong to a cervico-dorsal series of a single individual, preserved in several blocks. Some of them show elements in articulation. The members of Sauropterygia presents double-headed cervical ribs contact- ing with the parapophyses in the cervical centra, and with the diapophyses in the cervical neural arches. However, the dorsal ribs are holocephalous, and contact with the welldeveloped transverse processes of the dorsal neural arches (Rieppel, 2000). UPUAM 14072b and UPUAM 14072c are slightly smaller than UPUAM 14072a, and their transverse processes are smaller, indicating that they are situated ante- 


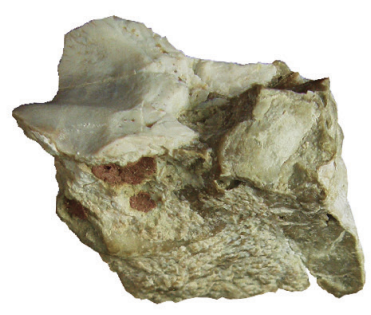

A

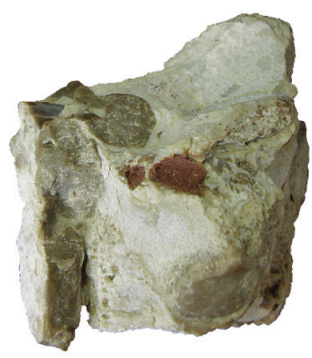

C
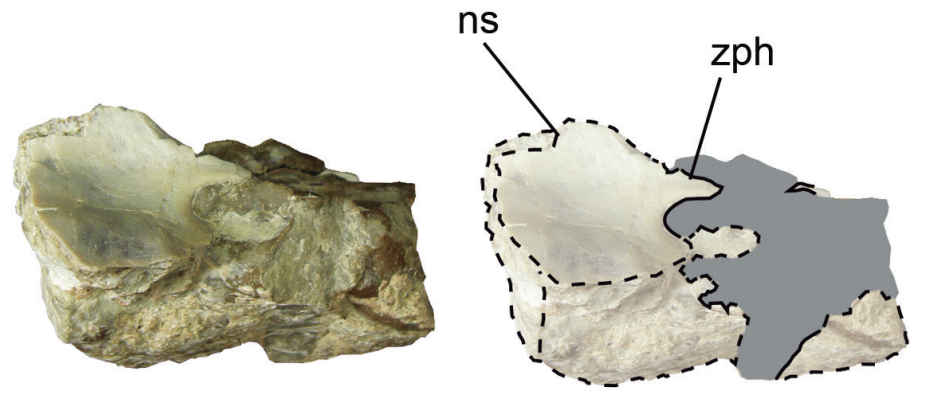

E

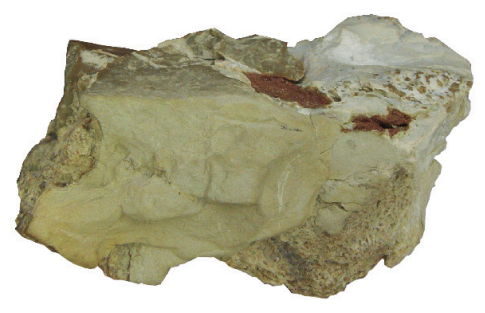

G
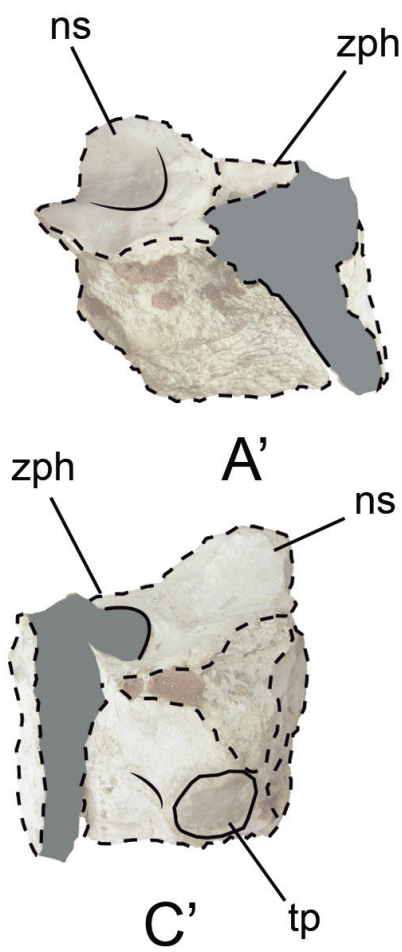

$E^{\prime}$

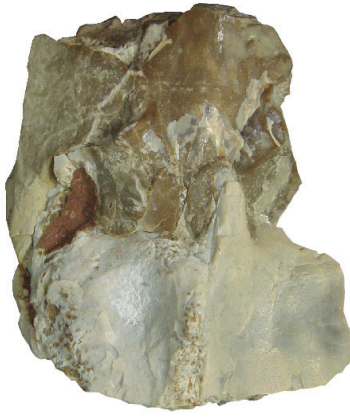

$\mathrm{F}$
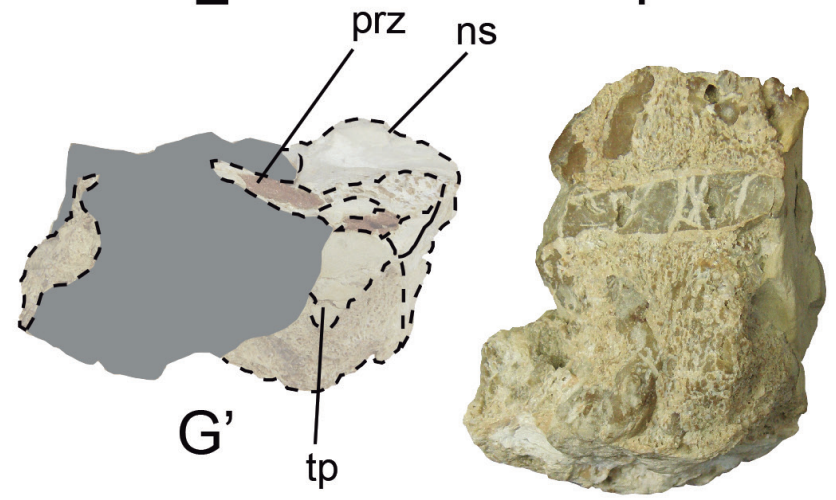

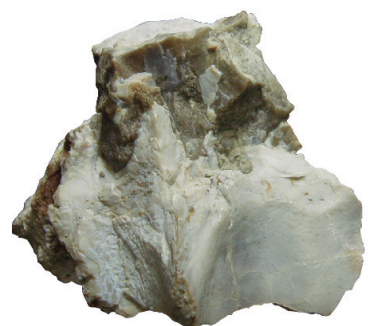

B

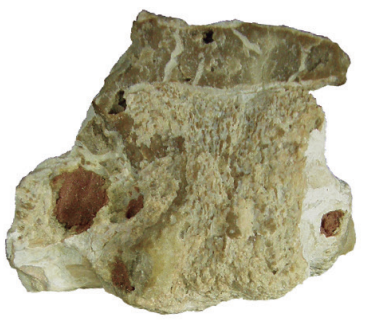

D
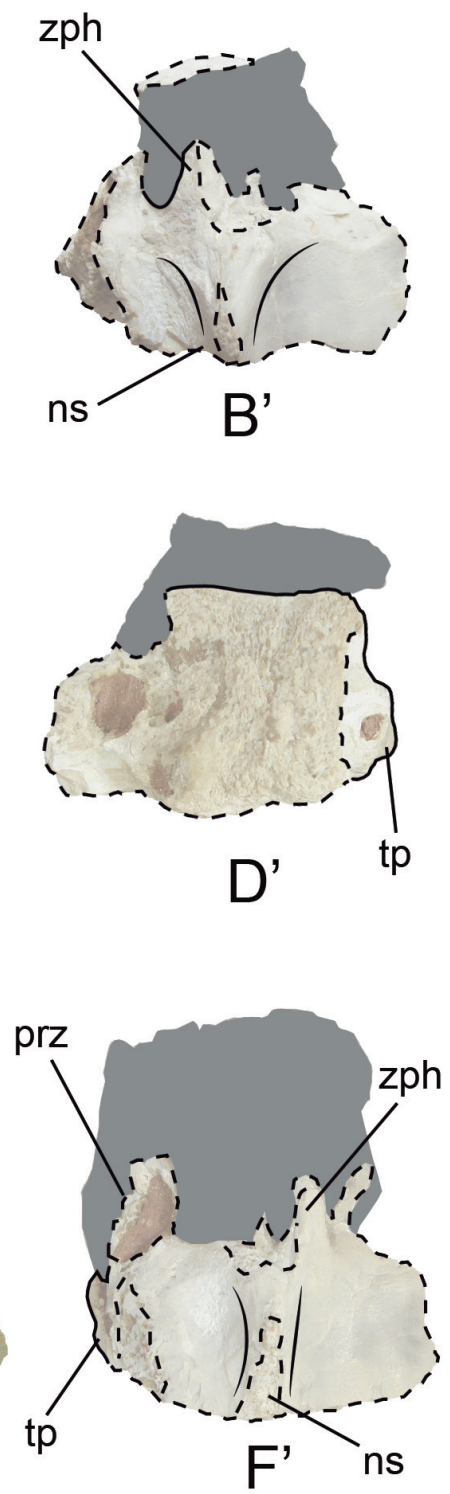

$\mathrm{H}$

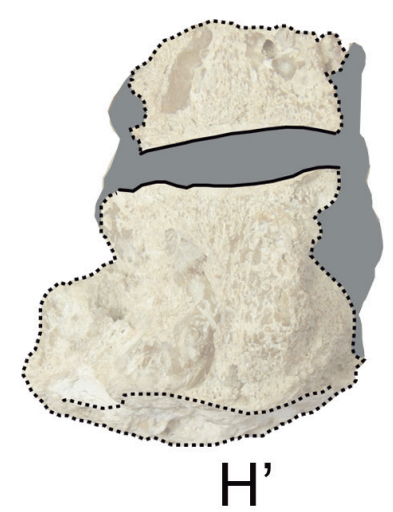

Fig. 4.- Cervico-dorsal vertebrae of Nothosaurus cf. giganteus from the upper Ladinian of Fuencaliente de Medinaceli (Soria Province, Spain). A-D, UPUAM 14702b vertebral remains in right lateral (A), dorsal (B), left lateral (C) and ventral (D) views. A'-D', schematic interpretations, in the same views. E-H, UPUAM 14702 c vertebral remains in right lateral (E), dorsal (F), left lateral (G) and ventral (H) views. E'-H', their schematic interpretations, in the same views. Grey areas represent sediment, and dashed lines indicate broken surfaces of bone. Anatomical abbreviations: ns, neural spine; prz, prezygapophysis; tp, transverse process; zph, zygosphene. Scale bar equals $20 \mathrm{~mm}$. 
riorly in the axial series. The preservation of the vertebrae from Fuencaliente de Medinaceli does not allow to know if the centra had parapophyses, a structure present in the cervical vertebrae but not in the dorsals. However, relative small transverse processes, which increase in size from the anterior to the posterior vertebrae position, are identified in the neural arches. Since well-developed transverse processes are present in the dorsal vertebrae of Sauropterygia, the described transverse processes allow to recognize the vertebrae from Fuencaliente de Medinaceli as situated at the posterior region of the cervical series or representing the anterior dorsals.

Several diagnostic characters allow the systematic determination of the vertebral remains studied here. The presence of a zygosphene-zygantrum articulation in addition to the prezygapophysis and postzygapophysis is an exclusive character for the members of Eosauropterygia (Rieppel, 1994). The platycoelous centra recognized in UPUAM 14072 allow to exclude its assignment to the European pachypleurosaurs, which present amphicoelous centra and pachyostotic zygapophyses (Rieppel, 2000). Some eosauropterygian taxa of problematic phylogenetic position can also be excluded. Several small forms from China, like Keichousaurus hui Young 1958, Dianopachysaurus dingi Liu, Rieppel, Jiang, Aitchinson, Motani, Zhang, Zhou and Sun 2011, and Qianxisaurus chajiangensis Cheng, Wu, Sato and Shan 2012, present zygapophyseal pachyostosis, like the European pachypleurosaurs (Lin and Rieppel, 1998; Liu et al., 2011; Cheng et al., 2012). This character is absent in the vertebrae from Fuencaliente de Medinaceli. Keichousaurus hui and Q. chajiangensis also presents amphicoelous centra, as well as the Chinese taxon Wumengosaurus delicatomandibularis Jiang, Rieppel, Motani, Hao, Sun, Schmitz and Sun 2008 (Jiang et al., 2008). Diandongosaurus acutidentatus Shang, Wu and Li 2011, from China, presents rhomboidal neural spines and elongated centra, this last character also being shared with the Chinese eosauropterygians Hanosaurus hupehensis Young 1972, and Majiashanosaurus discocoracoidis Jiang, Motani, Tintori, Rieppel, Chen, Huang, Zhang, Sun and Ji 2014 (Rieppel 1998b; Shang et al., 2011; Sato et al., 2014; Jiang et al., 2014), but not with UPUAM 14072. In addition, M. discocoracoidis presents laterally constrained centra in ventral view, not consistent with the Fuencaliente de Medinaceli vertebrae. The poor known taxa from China Chinchenia sungi Young 1965, Kwangisaurus orientalis Young 1959, and Sanchiaosaurus dengi Young 1965, have prominent transverse processes and, again, amphicoelous centra (Rieppel, 1999), unlike UPUAM 14072. The vertebrae from Fuencaliente de Medinaceli are not compatible with the members of Pistosauroidea, which present well-developed transverse processes in the neural arches (Sues, 1987; Sander et al., 1997; Rieppel, 2000; Ma et al., 2015). The vertebrae of Corosaurus alcovensis Case 1936, from the Lower Triassic of Wyoming (USA), and of the genus Cymatosaurus Fritsch 1894, from the Lower-Middle Triassic of Germany, do not present the same morphology that those from Fuencaliente de Medi- naceli. These two eosauropterygian taxa, previously classified as pistosauroids, have recently been excluded from this clade, having an uncertain systematic position (Ma et al., 2015; Liu et al., 2015). The vertebrae of C. alcovensis are amphicoelous, with long transverse processes, not consistent with UPUAM 14072 (Storrs, 1991; Rieppel, 1998c). The only probable postcranial material assigned to the genus $C y$ matosaurus also shows amphicoelous centra and prominent transverse process (Sander et al., 2014). The nothosauroid Simosaurus gaillardoti Meyer 1842 (i.e. the so far only known member of Simosauridae), from the Middle-Upper Triassic of Europe, Israel and Arabia, presents infraprezygapophyses and infrapostzygapophyses, additional articular elements in the neural arches that are exclusive for this taxon (Rieppel, 2000). UPUAM 14072 lacks infrazygapophyses, so these remains do not belong to a simosaurian nothosauroid. The neural arches of the members of Nothosauria are characterized by a well-developed bipartite zygosphene (Rieppel and Wild, 1996; Rieppel et al., 1997). The presence of a prominent bipartite zygosphene in the vertebrae from Fuencaliente de Medinaceli confirms that these remains belong to this clade. The nothosaur genus Lariosaurus (including its junior synonym Ceresiosaurus sensu Rieppel 1998a), presents, like the pachypleurosaurs, zygapophyseal pachyostosis, and very low neural spines (Rieppel, 1998a; 2000). As indicated, the vertebrae from Fuencaliente de Medinaceli lack these characters. The non-pachyostotic centra and neural arches in UPUAM 14072 are shared with the genus Nothosaurus within the clade Nothosauria, as well as the presence of platycoelous centra (Bickelmann and Sander, 2008).

Nothosaurus is a sauropterygian taxon known by several species, whose fossils have been found in the Middle and lower Upper Triassic of Europe, China, Israel and Tunisia (Rieppel and Wild, 1996; Rieppel et al., 1997; 1999; Rieppel, 2000; 2001; Albers and Rieppel, 2003; Li and Rieppel, 2004; Albers, 2005; Jiang et al., 2006; Shang, 2006; Bickelmann and Sander, 2008; Klein and Albers, 2009; Ji et al., 2014; Liu et al., 2014; Klein et al., 2015). Within this genus, the species Nothosaurus giganteus Münster 1834, presents autapomorphic neural arches according to Rieppel and Wild (1996) and Rieppel et al. (1999). In contrast with other Nothosaurus species known by postcranial elements, the neural arches in N. giganteus have low neural spines (Peyer, 1939; Rieppel and Wild, 1996). The height of the neural spines is a character that experiences interspecific variability within the genus Nothosaurus. In this sense, low neural spines are considered as a plesiomorphic character for this genus, whereas species with high neural spines are considered as more derived for this character (Rieppel and Wild, 1996). The neural arches in $N$. giganteus are massive, and present dome-shaped postzygapophyses, whereas the prezygapophyses are not pachyostotic. The transverse processes are high but not prominent, reaching the pedicels of the neural arch and the neurocentral suture. Therefore, the transverse processes do not project beyond the zygapophyses. The vertebrae recovered from Fuen- 

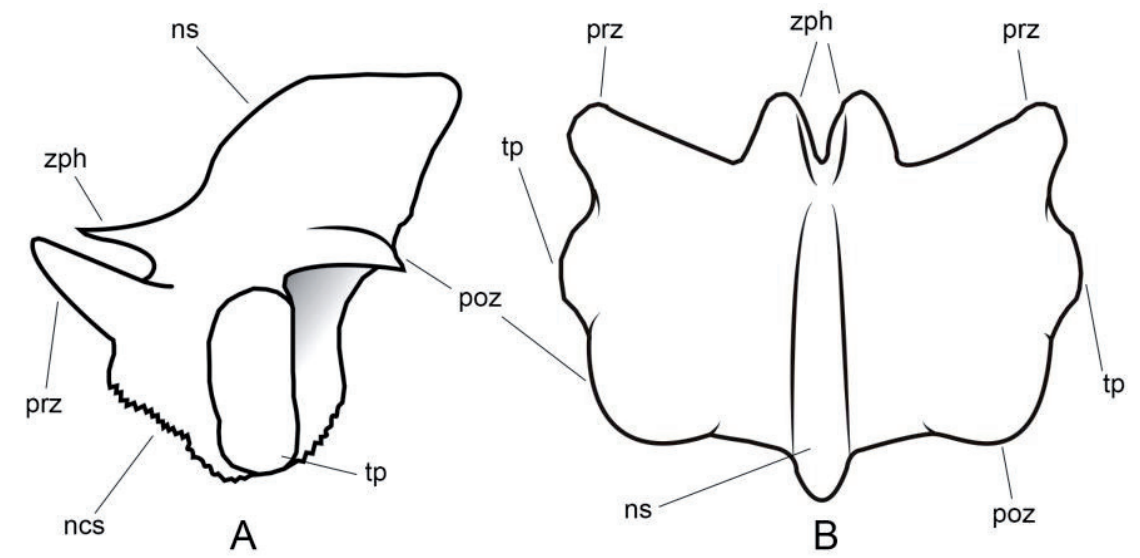

Fig. 5.- Hypothetical reconstruction of a Nothosaurus cf. giganteus complete and not-deformed neural arch of a dorsal vertebrae, from the upper Ladinian of Fuencaliente de Medinaceli (Soria Province, Spain). A, left lateral view. B, dorsal view. Anatomical abbreviations: ncs, neurocentral suture; ns, neural spine; poz, postzygapophysis; prz, prezygapophysis; tp, transverse process; zph, zygosphene. caliente de Medinaceli share all these exclusive characters (Fig. 5). Nothosaurus giganteus is a large nothosaur found in the upper Muschelkalk and the lower Keuper (in Anisian, Ladinian and Carnian levels, i.e. Middle-Upper Triassic) of Central Europe (mainly Germany), the Italian Alps and Israel (Dalla Vecchia, 1994; Rieppel and Wild, 1996; Rieppel et al., 1999; Rieppel and Dalla Vecchia, 2001; Diedrich, 2013). Although several species of Nothosaurus have been described, most of them are based mostly on cranial remains. Therefore, in spite of the remains of Fuencaliente de Medinaceli share a combination of vertebral characters so far only known in $N$. giganteus, we classify them as Nothosaurus cf. giganteus considering that the vertebrae of several of the described Nothosaurus species are poorly known or even unknown (e.g. Nothosaurus winterswijkensis Albers and Rieppel 2003, Nothosaurus rostellatus Shang 2006, Nothosaurus yangjuanensis Jiang, Masich, Hao, Sun and Sun 2006, Nothosaurus winkelhorsti Klein and Albers 2009).

Remains attributed to the genus Nothosaurus have been recovered from several localities of Spain, including the Muschelkalk of Royuela, Teruel (Kuhn-Schnyder, 1966); Siles, Jaén (Niemeyer, 2002); and Puente Génave-Villarodrigo, Jaén (Reolid et al., 2013). In addition, a new species of Nothosaurus was described, based on cranial material recovered from the Muschelkalk of Alcover (Tarragona Province), Nothosaurus cymatosauroides (Sanz, 1980; 1983), although the validity of the species was subsequently discussed (Rieppel, 2000). Although vertebral remains have been assigned to $N$. cymatosauroides, only their casts have been recognized, being poorly informative. Furthermore, some remains of questionable attribution to Nothosaurus have been recovered from the Spanish record. In this sense, a tooth and a partial dentary found at the Muschelkalk of the area of BienservidaVillarodrigo (Albacete-Jaén) was indicated as compatible with the genus Nothosaurus (Sanz, 1991). Elements putatively assigned to cf. Nothosaurus were found in the Muschelkalk of Canales de Molina, Guadalajara (Alférez et al., 1983), but they have not been studied yet, and that identification was not justified. In addition, Bauza Rullán (1955) described a vertebra assigned to Nothosaurus from the Muschelkalk of Sóller (Mallorca). This classification was posteriorly con- sidered as doubtful (Sanz, 1980; 1983). Based on Rubio et al. (2003), Knoll et al. (2004) suggested that the nothosaur vertebrae from several outcrops of the Keuper of Manzanera (Teruel) probably belong to Nothosaurus. However, this material presents infrazygapophyses that allows to refute this assignation, and to assign it to Simosaurus (Miguel Chaves et al., 2015). The nothosaur vertebrae found at Royuela, Siles and Puente Génave-Villarodrigo, the sites where confirmed Nothosaurus vertebral elements have been recovered (KuhnSchnyder, 1966; Niemeyer, 2002; Reolid et al., 2013), present high neural spines and relatively prominent and dorsoventrally short transverse processes. This morphology is not compatible with those of the vertebrae of $N$. giganteus nor with those from Fuencaliente de Medinaceli. Non-vertebral remains of Nothosaurus from the Iberian Peninsula cannot be assigned to $N$. giganteus either, due to they are not compatible with those of that taxon (e.g., the skull of $N$. cymatosauroides), or due to they are not informative enough at species level (e.g., appendicular elements from Siles and Puente Génave-Villarodrigo). Therefore, no element assigned to $N$. giganteus was hitherto found in the Spanish record.

The remains from Fuencaliente de Medinaceli represent the first potential finding of $N$. giganteus in the Iberian Peninsula. Its identification in Spain would be consistent with the wide geographical distribution of $N$. giganteus in the Western Tethys. The morphological incompatibility of the vertebrae from Fuencaliente de Medinaceli with other Spanish vertebral elements indisputably attributed to Nothosaurus (i.e., those from Royuela, Siles and Puente Génave-Villarodrigo), implies the presence of, at least, two different species of the sauropterygian Nothosaurus in the Middle Triassic of the Iberian Peninsula.

\section{Acknowledgements}

This research is funded by a FPI UNED Grant (ref. 0271864713 Y0SC001170). The authors thank Luis S. Alafont the information and the access to the material studied here. The authors thank Pedro Mocho and Adrián Páramo their help and comments. The authors thank the editors José López-Gómez and Javier Martín-Chivelet, and the reviewers 
R. de la Horra and J. Fortuny for their kind comments, which have helped improve this paper.

\section{References}

Adell Argiles, F., Bascones Alvira, L., Martínez Álvarez, F., Tena-Dávila Ruiz, M., La Moneda González, E., Rodríguez González, A. (1981): Hoja geológica num. 462 (Maranchón). Mapa Geológico de España E. 1:50000. Segunda serie, I.G.M.E., Madrid.

Alafont, L.S. (1992): Notosaurios y Placodontos (Reptilia) del Triásico Medio de Bienservida - Villarrodrigo.Instituto de Estudios albacetenses de la Excma.Diputación de Albacete, Spain, 131 p.

Alafont, L.S. (1999): Reptiles del Triásico. In: A. Aguirre, I. Rábano, I. (ed.), La huella del pasado: Fósiles de Castilla-La Mancha. Junta de Comunidades de Castilla-La Mancha, pp. 143-159.

Alafont, L.S., Sanz, J.L. (1996): Un nuevo Sauropterigio (Reptilia) en el Triásico de la Sierra de Prades (Tarragona). Cuadernos de Geología Ibérica 20, 313-329.

Albers, P.C.H. (2005): A new specimen of Nothosaurus marchicus with features that relate the taxon to Nothosaurus winterswijkensis. PalArch's Journal of Vertebrate Palaeontology 3(1), 1-7.

Albers, P.C.H., Rieppel, O. (2003): A new species of the sauropterygian genus Nothosaurus from the lower Muschelkalk of Winterswijk, The Netherlands. Journal of Paleontology 77(4), 738-744. doi:10.1666/0022-3360(2003)077<0738:ANSOTS >2.0.CO;2.

Alférez, F., Molero, G., Maldonado, E. (1983): Un nuevo yacimiento con vertebrados fósiles (Peces y Reptiles) en el Trías de la Cordillera Ibérica (Canales de Molina, Guadalajara). Real Sociedad Española de Historia Natural. VI Reunión Bienal, Santiago, p. 44.

Almela, A., Llopis Lladó, N. (1947): Hoja geológica num. 392 (Sabadell). Mapa Geológico de España E. 1:50.000. Segunda serie, I.G.M.E., Madrid.

Bauzá Rullán, J. (1955): Notas paleontológicas de Mallorca: sobre el hallazgo del Nothosaurus en el Trias. Boletín de la Sociedad de Historia Natural de Baleares 1, p. 87.

Bickelmann, C., Sander, P.M. (2008): A partial skeleton and isolated humeri of Nothosaurus (Reptilia: Eosauropterygia) from Winterswijk, The Netherlands. Journal of Vertebrate Paleontology 28(2), 326-338. doi:10.1671/0272-4634(2008)28[326:APSAIH]2.0.CO;2.

Cheng, Y-N., Wu, X-C., Sato, T., Shan, H-Y. (2012): A new eosauropterygian (Diapsida, Sauropterygia) from the Triassic of China. Journal of Vertebrate Paleontology 32(6), 1335-1349. doi:10.1080/0272463 4.2012.695983.

Dalla Vecchia, F.M. (1994): Reptile remains from the Middle-Upper Triassic of the Carnic and Julian Alps (Friuli-Venezia Giulia, Northeastern Italy). Gortania - Atti del Museo Friulano di Storia Naturale 15 (1993), 49-66.

Diedrich, C.G. (2013): Shallow marine sauropterygian reptile biodiversity and change in the Bad Sulza Formation (Illyrian, Middle Triassic) of Central Germany, and a contribution to the evolution of Nothosaurus in the Germanic Basin. New Mexico Museum of Natural History and Science Bulletin 61, 132-138.

Escudero-Mozo, M.J., Márquez-Aliaga, A., Goy, J., Martín-Chivelet, J., López-Gómez, J., Márquez, L., Arche, A., Plasencia, P., Pla, C., Marzo, M., Sánchez-Fernández, D. (2015): Middle Triassic carbonate platforms in Eastern Iberia: Evolution of their fauna and palaeogeographic significance in the western Tethys. Palaeogeography, Palaeoclimatology, Palaeoecology 417, 236-260. doi:10.1016/j.palaeo.2014.10.041.

Fortuny, J., Bolet, A., Sellés, A.G., Cartanyà, J., Galobart, À. (2011): New insights on the Permian and Triassic vertebrates from the Iberian Peninsula with emphasis on the Pyrenean and Catalonian basins. Journal of Iberian Geology 37, 65-86. doi:0.5209/rev_JIGE.2011. v37.n1.5.

García-Gil, S. (1990): Estudio sedimentológico y paleogeográfico del Triásico en el tercio noroccidental de la Cordillera Ibérica (Provincias de Guadalajara y Soria). Ph.D. thesis, Universidad Complutense de Madrid, Madrid, 524 p.

García-Gil, S. (1991): Las unidades litoestratigráficas del Muschelkalk en el NW de la Cordillera Ibérica (España). Boletín de la Real Sociedad Española de Historia Natural 86 (1-4), 21-51.

Ji, C., Jiang, D-Y., Rieppel, O., Motani, R., Tintori, A., Sun, Z-Y. (2014): A new specimen of Nothosaurus youngi from the Middle Triassic of Guizhou, China. Journal of Vertebrate Paleontology 34(2), 465-470. doi:10.1080/02724634.2013.808204.

Jiang, D.-Y., Maisch, M.W., Hao, W.-C., Sun, Y.-L., Sun, Z.-Y. (2006): Nothosaurus yangjuanensis n. sp. (Reptilia, Sauropterygia, Nothosauridae) from the middle Anisian (Middle Triassic) of Guizhou, southwestern China. NeuesJahrbuch für Geologie und Paläontologie, Monatshefte 5, 257-276.

Jiang, D.-Y., Rieppel, O., Motani, R., Hao, W.-C., Sun, Y.-L., Schmitz, L., Sun, Z.-Y. (2008): A new middle Triassic eosauropterygian (Reptilia, Sauropterygia) from Southwestern China. Journal of Vertebrate Paleontology 28 (4), 1055-1062. doi:10.1671/0272-4634-28.4.1055.

Jiang, D.-Y., Motani, R., Tintori, A., Rieppel, O., Chen, G.-B., Huang, J.-D., Zhang, R., Sun, Z.-Y., Ji, C. (2014): The Early Triassic eosauropterygian Majiashanosaurus discocoracoidis, gen. et sp. nov. (Reptilia, Sauropterygia), from Chaohu, Anhui Province, People's Republic of China. Journal of Vertebrate Paleontology 34 (5), 1044-1052. doi:10.1080/02724634.2014.846264.

Klein, N., Albers, P.C.H. (2009): A new species of the sauropsid reptile Nothosaurus from the Lower Muschelkalk of the western Germanic Basin, Winterswijk, The Netherlands. Acta Palaeontologica Polonica 54 (4), 589-598. doi:10.4202/app.2008.0083.

Klein, N., Voeten, D.F.A.E., Lankamp, J., Bleeker, R., Sichelschmidt, O.J., Liebrand, M., Nieweg, D.C., Sander, P.M. (2015): Postcranial material of Nothosaurus marchicus from the Lower Muschelkalk (Anisian) of Winterswijk, The Netherlands, with remarks on swimming styles and taphonomy. Paläontologische Zeitschrift 89, 961981. doi:10.1007/s12542-015-0273-5.

Knoll, F., López-Antoñanzas, R., Molina-Anadón, J.A. (2004): Filling a gap: Late Triassic nonmarine tetrapods from the Iberian Peninsula. Journal of Vertebrate Paleontology 24(3) - Abstracts, p. 79A.

Kuhn-Schnyder, E. (1966): Über Wirbeltier-Reste ausdem Muschelkalk der Provinz Teruel (Spanien). Oberrhein. Geol. Abh. 15, 99-106.

Lapparent A.F. (1966): Noveaux gisements de reptiles mesozoiques en Espagne. Notas y Comunicaciones del Instituto Geológico y Minero de España 84, 103-110.

Li, J., Rieppel, O. (2004): A new nothosaur from Middle Triassic of Guizhou, China. Vertebrata PalAsiatica 42(1), 1-12.

Lin, K., Rieppel, O. (1998): Functional Morphology and Ontogeny of Keichousaurus hui (Reptilia, Sauropterygia). Fieldiana: Geology 39, $1-35$.

Liu, J., Rieppel, O., Jiang, D.-Y., Aitchison, J., Motani, R., Zhang, Q.Y., Zhou, C.-Y., Sun, Y.-Y. (2011): A new pachypleurosaur (Reptilia: Rauropterygia) from the lower Middle Triassic of Southwestern China and the phylogenetic relationships of Chinese pachypleurosaurs. Journal of Vertebrate Paleontology 31 (2), 292-302. doi:10.1080/02 724634.2011.550363.

Liu, J., Hu, S.-X., Rieppel, O., Jiang, D.-Y., Benton, M.J., Kelley, N.P., Aitchison, J.C., Zhou, C.-Y., Wen, W., Huang, J.-Y., Xie, T., Lv, T. (2014): A gigantic nothosaur (Reptilia: Sauropterygia) from the Middle Triassic of SW China and its implication for the Triassic biotic recovery. Scientific Reports 4, 7142, 1-9. doi:10.1038/srep07142.

Liu, X.-Q., Lin, W.-B., Rieppel, O., Sun, Z.-Y., Li, Z.-G., Lu, H., Jiang, D.-Y. (2015): A new specimen of Diandongosaurus acutidentatus (Sauropterygia) from the Middle Triassic of Yunnan, China. Verte- 
brata PalAsiatica (advance online publication), 1-10.

López-Gómez, J. (1985): Sedimentología y estratigrafía de los materiales pérmicos y triásicos del sector SE de la Rama Castellana de la Cordillera Ibérica entre Cueva de Hierro y Chelva (provincias de Cuenca y Valencia). Seminarios de Estratigrafia, Serie Monografias $11,1-344$.

Ma, L.-T., Jiang, D.-Y., Rieppel, O., Motani, R., Tintori, A. (2015): A new pistosauroid (Reptilia, Sauropterygia) from the late Ladinian Xingyi marine reptile level, southwestern China. Journal of Vertebrate Paleontology 35 (1), 1-6. doi:10.1080/02724634.2014.881832.

Márquez-Aliaga, A., García-Gil, S. (1991): Paleontología y ambientes del Triásico Medio en el sector noroccidental de la Cordillera Ibérica (Provincias de Soria y Guadalajara, España). Estudios Geológicos 47, 85-95.

Miguel Chaves, C. de, Pérez-García, A., Cobos, A., Royo-Torres, R., Ortega, F., Alcalá, L. (2015): A diverse Late Triassic tetrapod fauna from Manzanera (Teruel, Spain). Geobios 48, 479-490. doi:10.1016/j.geobios.2015.09.002.

Niemeyer, J. (2002): Invertebraten und Vertebraten aus dem Muschelkalk von Siles (Jaén), Spanien. Münstersche Forschungen zur Geologie und Paläontologie 94, 1-98.

Pérez-Arlucea, M., Sopeña, A. (1985): Estratigrafía del Pérmico y Triásico en el sector central de la Rama Castellana de la Cordillera Ibérica (provincias de Guadalajara y Teruel). Estudios Geológicos 41, 207-222.

Peyer, B (1939). Die Triasfauna der Tessiner Kalkalpen. XIV. Paranothosaurus amsleri nov. gen. nov. spec. Abhandlungen der schweizerschen Palaontologischen Gesellschaft 62, 1-87.

Pinna, G. (1990). I rettili placodonti dei terreni di Spagna. Atti della Societa Italiana di Scienze Naturali e del Museo Civico di Storia Naturale di Milano 131, 137-143.

Quesada, J.M., Aguera González, S. (2005). Descripción del primer ejemplar de Ceresiosaurus (Reptilia: Sauropterygia), hallado en la Península Ibérica en al Ladiniense (Triásico Medio) de Mont-ral Alcover (Tarragona). Estudios Geológicos 61, 247-269. doi:10.3989/ egeol.05613-667.

Ramos, A. (1979): Estratigrafía y paleogeografía del Pérmico y Triásico al oeste de Molina de Aragón (Provincia de Guadalajara). Seminarios de Estratigrafia, Serie Monografías 6, 1-313.

Reolid, M., Pérez-Valera, F., Benton, M.J., Reolid, J. (2013): Marine flooding in continental Triassic facies identified by a nothosaur and placodont bonebed (South Iberian Paleomargin). Facies 60, 277-293. doi: 10.1007/s10347-013-0360-6

Rieppel, O. (1994): Osteology of Simosaurus gaillardoti and the relationships of stem-group Sauropterygia. Fieldiana: Geology 28, 1-85.

Rieppel, O. (1998a): The status of the sauropterygian reptile genera Ceresiosaurus, Lariosaurus, and Silvestrosaurus from the Middle Triassic of Europe. Fieldiana: Geology 38, 1-46.

Rieppel, O. (1998b): The systematic status of Hanosaurus hupehensis (Reptilia, Sauropterygia) from the Triassic of China. Journal of Vertebrate Paleontology 18(3), 545-557. doi:10.1080/02724634.1998.1 0011082.

Rieppel, O. (1998c): Corosaurus alcovensis Case and the phylogenetic interrelationships of Triassic stem-group Sauropterygia. Zoological Journal of the Linnean Society 124(1), 1-41. doi:10.1111/j.1096-3642.1998.tb00568.x.

Rieppel, O. (1999): The sauropterygian genera Chinchenia, Kwangsisaurus, and Sanchiaosaurus from the Lower and Middle Triassic of China. Journal of Vertebrate Paleontology 19(2), 321-337. doi:10.10 80/02724634.1999.10011144.

Rieppel, O. (2000): Part 12A. Sauropterygia I. In: P. Wellnhofer (ed.), Handbuch der Paläoherpetologie. Verlag Friedrich Pfeil, München, pp. 1-134.
Rieppel, O. (2001): A new species of Nothosaurus (Reptilia: Sauropterygia) from the Upper Muschelkalk (Lower Ladinian) of southwestern Germany. Paleontographica A 263, 137-161.

Rieppel, O., Wild, R. (1996): A revision of the genus Nothosaurus (Reptilia: Sauropterygia) from the Germanic Triassic, with comments on the status of Conchiosaurus clavatus. Fieldiana: Geology 34, 1-82.

Rieppel, O., Hagdorn, H. (1998): Fossil reptiles from the Spanish Muschelkalk (Mont-ral and Alcover, Province Tarragona). Historical Biology 13, 77-97. doi:10.1080/08912969809386575.

Rieppel, O., Dalla Vecchia, F.M. (2001): Marine reptiles from the Triassic of the Tre Venezie, northeastern Italy. Fieldiana: Geology 44, $1-25$.

Rieppel, O., Mazin, J.M., Tchernov, E. (1997): Speciation along rifting continental margins: a new nothosaur from the Negev (Israel). Earth and Planetary Sciences 325, 991-997.

Rieppel, O., Mazin, J.M., Tchernov, E. (1999): Sauropterygia from the Middle Triassic of Makhtesh Ramon, Negev, Israel. Fieldiana: Geology 40, 1-85.

Rubio, C., Díez Ferrer, J.B., Ferrer, J., Gámez Vintaned, J.A., Sender, L.M., Zianni, H. (2003): La Comarca de Gúdar - Javalambre da a conocer su rico patrimonio geológico y paleontológico. Naturaleza Aragonesa 11, 21-34.

Sander, P.M., Rieppel, O.C., Bucher, H. (1997): A new pistosaurid (Reptilia: Sauropterygia) from the Middle Triassic of Nevada and its implications for the origin of the plesiosaurs. Journal of Vertebrate Paleontology 17(3), 526-533. doi:10.1080/02724634.1997.10010999.

Sander, P.M., Klein, N., Albers, P.C.H., Bickelmann, C., Winkelhorst, H. (2014): Postcranial morphology of a basal Pistosauroidea (Sauropterygia) from the Lower Muschelkalk of Winterswijk, The Netherlands. Paläontologische Zeitschrift 88, 55-71. doi:10.1007/s12542-0150273-5.

Sanz, J.L. (1976): Lariosaurus balsami (Sauropterygia, Reptilia) de Estada (Huesca). Estudios Geológicos 32, 547-567.

Sanz, J.L. (1980): Los notosaurios españoles. Análisis filogenético y sistemático de los sauropterigios triásicos. Ph.D. thesis, Universidad Complutense de Madrid, Madrid, $442 \mathrm{p}$.

Sanz, J.L. (1983): Los notosaurios (Reptilia, Sauropterygia) españoles. Estudios Geológicos 39, 193-215.

Sanz, J.L. (1991): Notosaurios y placodontos (Reptilia). Su registro en el yacimiento de Bienservida-Villarodrigo. Actas de las Jornadas sobre el Medio Natural Albacetense, Albacete, pp. 17-32.

Sato, T., Cheng, Y.-N., Wu, X.-C., Shan, H-Y. (2014): Diandongosaurus acutidentatus Shang, Wu and Li, 2011 (Diapsida: Sauropterygia) and the relationships of Chinese eosauropterygians. Geological Magazine 151 (1), 121-133. doi:10.1017/S0016756813000356.

Shang, Q. (2006): A new species of Nothosaurus from the early Middle Triassic of Guizhou, China. Vertebrata PalAsiatica 4(3), 237-249.

Shang, Q., Wu, X., Li, C. (2011): A new eosauropterygian from Middle Triassic of eastern Yunnan Province, Southwestern China. Vertebrata PalAsiatica 49(2), 155-171.

Storrs, G. W. (1991): Anatomy and relationships of Corosaurus alcovensis (Diapsida: Sauropterygia) and the Triassic Alcova Limestone of Wyoming. Bulletin of the Peabody Museum of Natural History Yale University 44, 1-151.

Sues, H.D. (1987): Postcranial skeleton of Pistosaurus and interrelationships of the Sauropterygia (Diapsida). Zoological Journal of the Linnean Society 90, 109-131. doi:10.1111/j.1096-3642.1987.tb01351.x.

Virgili, C. (1958): El Triásico de los Catalánides. Boletín del Instituto Geológico y Minero 69, 301-311.

Westphal, F. (1975): Bauprinzipien im Panzer der Placodonten (Reptilia triadica). Paliiontologische Zeitschrift 49, 97-125. 